\title{
Perencanaan Core Capability Pegawai Dalam Rangka Menghadapi Era Kompetitif (Studi di Pusat Konservasi Tumbuhan Kebun Raya LIPI)
}

\author{
Novia Putri Andriani M.D ${ }^{\text {a }}$, Endah Setyowati ${ }^{\text {a }}$ \\ ${ }^{a}$ Universitas Brawijaya, Malang, Jawa Timur, Indonesia
}

INFORMASI ARTIKEL

Article history:

Dikirim tanggal: 02 November 2018

Revisi pertama tanggal: 26 Desember 2018

Diterima tanggal: 08 April 2019

Tersedia online tanggal: 23 April 2019

Keywords: core capability, human resources planning, bureucratic reform

\section{ABSTRACT}

This research was motivated by Civil Servant Apparatus regulation which demanded changes in the bureaucratic system. The purpose of the research is to plan employee core capability in the skill and knowledge dimensions towards the ASN era. This type of research uses a description method with a qualitative approach. The results show that planning of employee core capability is done by analyzing organizational objectives, internal and external environment of Human Resources, forecasting Human Resources needs, and planning development strategies by merit system and knowledge management.

\section{INTISARI}

Penelitian ini dilatarbelakangi oleh Undang-Undang tentang Aparatur Sipil Negara yang menuntut adanya perubahan dalam sistem birokrasi. Tujuan penelitian yang dilakukan adalah untuk merencanakan core capability pegawai pada dimensi skill dan knowledge dalam rangka menghadapi era kompetitif. Jenis penelitian ini menggunakan metode deskripsi dengan pendekatan kualitatif. Hasil penelitian menunjukkan bahwa perencanaan core capability pegawai yang dilakukan dengan menganalisis tujuan organisasi, lingkungan internal serta eksternal sumber daya manusia, meramalkan kebutuhan sumber daya manusia, serta merencanakan strategi pengembangannya melalui sistem merit dan knowledge management.

2019 FIA UB. All rights reserved.

\section{Pendahuluan}

Krisis ekonomi pada Tahun 1997 menyebabkan tuntutan dari masyarakat untuk merubah sistem penyelenggaraan pemerintahan di Indonesia. Oleh karena itu reformasi birokrasi hadir untuk memenuhi tujuan bangsa Indonesia. Thoha (2008:106) menyatakan bahwa adanya reformasi birokrasi bisa disebabkan oleh adanya kebutuhan melakukan perubahan dan pembaharuan. Pada Undang-Undang Nomor 17 Tahun 2007 tentang RPJPN 2005-2025; arah reformasi birokrasi salah satunya dengan melakukan pembangunan aparatur negara untuk meningkatkan profesionalisme aparatur negara dan untuk mewujudkan tata pemerintahan yang baik.

Pada Tahun 2025, cita-cita besar birokrasi pemerintahan di Indonesia diharapkan dapat lebih profesional dan berintegritas tinggi sehingga Indonesia berada pada fase yang benar-benar bergerak menuju negara maju. Untuk mencapai tujuan tersebut, berlanjut pada RPJM ketiga 2015-2019 pembangunan ASN diharapkan berubah menjadi Smart ASN. Salah satu tujuan dari penerbitan Undang - Undang ASN adalah untuk mewujudkan tata kelola aparatur sipil negara sebagai profesi yang memiliki kewajiban mengelola dan

* Corresponding author. Tel.: +62-822-3123-6036; e-mail: novia.mahardheny@ gmail.com 
mengembangkan dirinya dan mempertanggungjawabkan kinerjanya serta menerapkan prinsip merit.

Pada pasal 162 dalam Peraturan Pemerintah Nomor 11 Tahun 2017; dinyatakan bahwa pengembangan kompetensi merupakan salah satu dari manajemen karir PNS yang dilakukan dengan sistem merit. Penilaian kinerja pada era kompetitif yang didasarkan pada kualifikasi, kompetensi, dan kinerja memberikan tantangan tersendiri. Dahulunya, kondisi demikan menyiratkan kondisi dimana administrasi kepegawaian yang bersifat legalistik. Berbagai aktivitas kepegawaian lebih dipahami sebagai sequence atau runtutan aktivitas. (Muluk, 2008:148).

Melihat dari penjelasan tentang kondisi dari administrasi kepegawaian perlu diupayakan cara untuk mengubah ataupun mengurangi patologi berupa kekakuan inti organisasi dengan memberdayakan kemampuan inti (core capability) dari sebuah organisasi (Barton, 1995). Adanya kemampuan inti yang berada dalam suatu organisasi tidak dapat berjalan dengan sendirinya. Oleh karena itu, kemampuan inti harus didukung dengan aktivitas tertentu untuk mengembangkan juga memeliharanya.

Kondisi pegawai di PKT Kebun Raya-LIPI berdasarkan tingkat pendidikan lebih dari 50\% di tingkat SMA dan dibawahnya. Kemudian ditingkat usia lebih dari 50\% juga menuju usia yang tidak produktif lagi. Hal tersebut juga menjadi kelemahan dari sebuah organisasi mengingat bahwa perkembangan semakin kompleks dan kondisi pegawai juga harus menyesuaikan. Disisi lain, adanya kondisi SDM yang kurang dan tidak merata muncul adanya gap yang berhubungan dengan perolehan pengembangan kemampuan dan kompetensi pegawai yang hanya sering diikuti oleh sebagian pegawai saja. Namun PKT Kebun Raya-LIPI juga perlu menganalisis bagaimana cara lain agar kemampuan yang berisi knowledge dan skill pegawai dapat dikembangkan disemua lini pegawai. Berdasarkan uraian diatas, peneliti ingin menganalisis perencanaan core capabilitiy ASN di PKT Kebun Raya.

\section{Teori}

\subsection{Teori Perencanaan}

Faludi (1973:7) untuk melakukan perencanaan diperlukan adanya teori perencanaan (planning theory) yang dibedakan menjadi dua, yakni teori merencana (theory of planning) dan teori di dalam perencanaan (theory in planning). Menurut Faludi ini, penyerapan substansi metode dari disiplin ilmu lain sering disebut substantive theory atau theory in planning. Sementara teori perencanaan disebut sebagai procedural theory atau theory of planning.

Dalam perencanaan mengenai core capability pegawai pada penelitian ini menggunakan perencanaan efektif yang dikemukakan oleh Faludi (1973:7). Perencanaan efektif diartikan sebagai perencanaan kolaborasi antara perencanaan prosedural dan perencanaan substantif dimana keduanya tidak dapat berdiri sendiri dalam meresepon masalah-masalah publik. Teori perencanaan strategis sebagai perencanaan prosedural digunakan agar terjadi urutan logis untuk merenanakan sesuatu. Teori perencanaan sumber daya manusia sebagai perencanaan substantif digunakan karena penelitian ini merupakan bagian dari sumber daya manusia. Diharapkan dengan adanya kolaborasi perencanaan tersebut maka perencanaan kemampuan pegawai di PKT Kebun Raya-LIPI mampu mendapatkan perencanaan yang efektif.

\subsection{Perencanaan Strategis}

Menurut Bryson (1999:55) langkah-langkah perencanaan strategis dalam organisasi publik adalah:

a) Identifikasi mandate organisasi, yaitu upaya untuk memperjelas sebenarnya apa yang menjadi tugas pokok dari suatu organisasi tersebut. Hal ini berkaitan dengan identifikasi mengenai apa yang harus dilakukan oleh organisasi dan apa yang tidak boleh dilakukan oleh organisasi dalam menjalankan kegiatannya. Pada organisasi sektor publik/ nirlaba hal ini terkait dengan peraturan-peraturan yang mengatur penyelenggaraan organisasi itu sendiri;

b) Memperjelas misi dan nilai-nilai organisasi, dikaitkan dengan mandat yang telah teridentifikasi dengan jelas. Pada level ini organsasi harus dianggap sebagai alat untuk mencapai suatu kondisi tertentu, bukan sebagai tujuan. Titik sukses dari langkah ini adalah identifikasi terhadap stakeholder kunci, karena setiap misi yang dirumuskan dalam rangka memenuhi kepuasan stakeholder kunci;

c) Penilaian terhadap lingkungan eksternal, mengeksplorasi lingkungan diluar organisasi untuk mengidentifikasi peluang dan ancaman yang dihadapi organisasi. Lingkungan diluar organisasi meliputi politik, ekonomi, sosial dan teknologi, yang dalam hal ini organisasi tidak dapat mempengaruhi lingkungan eksternal tersebut;

d) Penilaian lingkungan internal, untuk mengetahui kekuatan dan kelamahan yang dimiliki organisasi. Dalam hal ini organisasi dapat melakukan dengan memantau sumberdaya yang dimiliki (inputs), strategi yang sedang dilaksanakan (proses), dan kinerja organisasi (outputs). Informasi mengenai kinerja juga diperlukan disini untuk menilai kelemahankelemahan yang dimiliki;

e) Identifikasi isu-isu strategis yang dihadapi;

f) Perumusan strategi dalam rangka mengatasi isu-isu, diartikan sebagai pola tujuan, kebijakan, program, kegiatan, rencana penggunaan sumber daya, terkait apa yang perlu dilakukan untuk mengatasi isu-isu; dan 
g) Menetapkan visi bagi organisasi yang efektif di masa depan, merupakan deskripsi mengenai bagaimana seharusnya organisasi sehingga berhasil mengimplementasikan strategi dan mencapai seluruh potensinya.

Karakter perencanaan strategis bersifat komprehensif karena semua aspek dikaji tetapi hanya berkaitan dengan isu strategis, hasil kajiannya bersifat menyeluruh bukan hanya aspek fisik serta memperhitungkan sumber daya yang tersedia. Dalam perencanaan yang dilakukan dalam penelitian ini, perencanaan strategis sebagai instrumen untuk mengkaji salah satu sumber daya yang tersedia yaitu sumber daya manusia. Langkah-langkah perencanaan strategis yang dikemukakan oleh Bryson di atas merupakan gambaran langkah-langkah untuk keseluruhan aspek organisasi. Melalui perencanaan efektif yang dikemukakan oleh Faludi (1973), perencanaan strategis bersifat menjembatani agar perencanaan lebih prosedural. Perencanaan prosedural memerlukan kolaborasi dengan perencanaan substantif.

\subsection{Perencanaan Sumber Daya Manusia}

Mathis \& Jackson (2006:53) berpendapat bahwa perencanaan sumber daya manusia memberikan petunjuk masa depan, menentukan dimasa tenaga kerja dapat diperoleh, kapan tenaga kerja akan dibutuhkan, dan pelatihan dan pengembangan jenis apa yang harus dimiliki tenaga kerja. Mathis dan Jackson (2006) menyatakan perencanaan sumber daya manusia dimulai dengan mempertimbangkan tujuan dan strategi organisasional. Kemudian dilakukan penilaian baik eksternal maupun internal akan kebutuhan dan sumber pasokan sumber daya manusia dan mengembangkan peramalan.

Setelah dilakukan penilaian, peramalan harus dikembangkan untuk mengidentifikasi hubungan antara penawaran dan permintaan untuk sumber daya manusia. Baru kemudian manajemen memformulasikan strategi sumber daya manusia dan merencanakan untuk menutupi ketidakseimbangan yang ada, baik untuk jangka pendek maupun jangka panjang.

\subsection{Core Capability (Kemampuan Inti)}

Barton (1995:111) menyatakan munculnya kemampuan inti (core capability) sebenarnya bukan hal yang baru. Berbeda dengan konsep kompetensi inti yang diusung oleh Prahalad \& Hamel (1990) yang mendefinisikan kompetensi inti sebagai pengetahuan kolektif organisasi tentang cara mengkoordinasikan beragam keterampilan dan mengintegrasikan teknologi yang dimiliki organisasi. Konsep ini didasarkan pada serangkaian tes yang mengidentifikasi sumber daya organisasi yang menawarkan nilai strategis terbesar.
Empat dimensi kemampuan inti yaitu pengetahuan dan keterampilan anggota organisasi (employee knowledge and skill), sistem fisik (physical technical system), sistem manajerial (managerial system), serta nilai atau norma (values and norms). Dimensi pengetahuan dan keterampilan anggota organisasi dianggap sebagai dimensi yang paling berhubungan dengan kemampuan inti. Ia merupakan pengetahuan dan kemampuan teknologi yang terakumulasi dalam benak manusia.

Perencanaan sumber daya manusia dalam penelitian ini melengkapi perencanaan substantif dari perencanaan efektif yang dikemukakan oleh Faludi (1973). Berhubungan dengan era kompetitif sekarang terutam kemampuan pegawai harus diatur dengan baik agar keberadaannya juga dapat memaksimalkan peran mereka untuk menuju tujuan pembangunan nasional.

\section{Metode Penelitian}

Penelitian ini menggunakan jenis penelitian kualitatif dengan pendekatan analisis deskriptif. Alasan peneliti menggunakan penelitian kualitatif karena ingin mengetahui kejelasan masalah yang akan dibahas serta mengetahui gambaran secara keseluruhan tentang bagaimana perencanaan core capability pegawai dalam menghadapi era kompetitif. Fokus penelitian yang diteliti adalah perencanaan core capability pegawai dalam menghadapi era kompetitif di Pusat Konservasi Tumbuhan Kebun Raya-LIPI, yang meliputi:

a) Identifikasi tujuan dari organisasi;

b) Penilaian terhadap lingkungan SDM;

c) Penilaian terhadap lingkungan eksternal SDM;

d) Meramalkan kebutuhan SDM; dan

e) Merumuskan strategi pengembangan SDM.

Pengumpulan data dilakukan dengan cara wawancara dengan informan, observasi fenomena, atau peristiwa, dan menelaah dokumen.

Metode analisis yang digunakan dalam penelitian ini adalah metode analisis model interaktif yang dikembangkan oleh Miles \& Huberman (2014). Metode ini terdiri dari empat proses, yaitu: data collection, data condensation, data display, dan conclusion drawing.

\section{Hasil Penelitian dan Pembahasan}

Faludi (1973:7) yang membedakan teori merencana (theory of planning) dan teori dalam perencanaan (theory in planning) tidak dapat dipisahkan sehingga diharapkan membentuk kolaborasi sehingga disebut perencanaan efektif. Theory of planning dalam penelitian ini menggunakan perencanaan strategis oleh Bryson (2004:13) yang mengartikan perencanaan strategis sebagai upaya untuk memandu apa yang dikerjakan dengan mengkaji isu strategis organisasi. 
Disamping itu, theory in planning dalam penelitian ini menggunakan perencanaan sumber daya manusia oleh Mathis \& Jackson (2006) yang menyatakan perencanaan sumber daya manusia memberikan petunjuk masa depan, menentukan tenaga kerja, dan pengembangan apa yang perlu dilakukan. Perencanaan core capability pegawai yang ada di PKT Kebun Raya LIPI dengan perencanaan efektif yang dikemukakan oleh Faludi (1973) dapat dilihat sebagai berikut:

\subsection{Identifikasi Tujuan Organisasi}

Sebagaimana pendapat dari Mathis dan Jasckson (2006) bahwa rencana sumber daya manusia merupakan penyediaan peta jalan untuk masa depan. Oleh karena itu, tujuan dari suatu organisasi harus memiliki kejelasan arah. Misi lembaga non pemerintahan yang jelas merupakan salah satu tahapan dari perencanaan strategis menurut Bryson (2004). PKT Kebun Raya-LIPI telah memiliki visi, misi, dan tugas pokok satuan kerja. Selain itu pada tataran yang lebih implementatif, untuk mewujudkan Undang-Undang Republik Indonesia Nomor 17 Tahun 2007 tentang Rencana Pembangunan Jangka Panjang Nasional (RPJPN) 2005-2025; pada Tahun 2018 ini PKT Kebun Raya LIPI memiliki tujuan strategis untuk menjabarkan visi dan misi. Terdapat sembilan poin yang disebutkan dalan tujuan strategis satuan kerja.

Dalam sembilan tujuan strategis yang disebutkan terdapat salah satu dari poin c yang menyebutkan bahwa:

Memperkuat kompetensi inti dibidang penelitian konservasi, domestikasi, botani ekonomi dan reintroduksi, pemulihan tumbuhan dan perubahan iklim, melalui aksi-aksi konservasi dan penyiapan bahan-bahan hasil penelitian untuk digunakan dalam perumusan kebijakan yang terkait dengan bidang konservasi, pengembangan tumbuhan-tumbuhan yang berpotensi untuk pemanfaatan yang berkelanjutan, maupun pemulihan jenis-jenis tumbuhan terancam kepunahan dan/ atau kawasan terdegradasi.

Berdasarkan wawancara yang telah dilakukan dengan Tim Perencanaan, Monitoring, dan Evaluasi hal tersebut tidak menjadi patokan mengenai kemampuan dari pegawai lainnya untuk mewujudkan tujuan dari organisasi. Banyak kemampuan yang diperlukan untuk mendukung dari kompetensi inti yang ada pada tujuan strategis satuan kerja tersebut.

Rencana strategis LIPI Tahun 2015-2019 diproyeksikan satuan kerja menjadi Perjanjian Kinerja (PK). Menurut wawancara penulis bahwa pengembangan SDM berada pada poin ke-8, yakni meningkatkan pengembangan kompetensi SDM peneliti Indonesia. Dimana target dari perjanjian kinerja tersebut adalah berapa banyak jumlah pegawai yang mengikuti pelatihan. Hal tersebut secara tersirat bahwa pengembangan SDM menjadi salah satu rencana stategis LIPI dan juga menjadi perjanjian kinerja setiap tahun di tingkat satuan kerja. Hal tersebut menjadi penting untuk diperhatikan. Mathis \& Jackson (2006) menyatakan bahwa Sumber Daya Manusia merupakan sumber kekuatan untuk menciptakan keunggulan kompetitif dari suatu organisasi. Tujuan strategis yang disusun oleh PKT Kebun Raya LIPI merupakan suatu bentuk pemikiran jangka panjang dimana support melalui SDM diperlukan dalam hal ini.

\subsection{Penilaian terhadap Lingkungan Internal SDM}

Mathis \& Jackson (2006) perencanaan sumber daya manusia selanjutnya dilakukan melalui penilaian lingkungan internal organisasi. Sementara Bryson (1999:55) perencanaan srategis dalam organisasi publik mengenai penilaian lingkungan internal organisasi dilakukan dengan memantau sumberdaya yang dimiliki (input), strategi yang sedang dilaksanakan (process), serta kinerja organisasi (output). Dalam tataran sumberdaya organisasi PKT Kebun Raya LIPI terdiri dari sumber daya manusia, anggaran, juga sarana dan prasarana.

Oleh karena itu penelitian yang dilakukan merujuk pada penilaian internal salah satu sumber daya organisasi, yakni sumber daya manusia. Di PKT Kebun raya-LIPI memiliki dari total 262 orang Aparatur Sipil Negara, sebanyak 137 pegawai menduduki sembilan jabatan fungsional. Di PKT Kebun Raya LIPI terdapat 50\% lebih pegawai masih memiliki pendidikan dibawah Sarjana. Dilihat dari segi usia terdapat 50\% lebih ASN memasuki usia yang tidak produktif lagi. Hal tersebut menjadi kelemahan satuan kerja mengingat kondisi sistem pemerintahan yang semakin dinamis menuntut adanya perubahan. Terlebih bahwa era kompetitif menuntut sumber daya manusia menuju competitive zone.

Strategi yang dilaksanakan mengenai sumber daya manusia dilakukan oleh Subbagian Kepegawaian. Perencanaan pelatihan dan pendidikan dilakukan setiap tahun dan dituangkan dalam Rencana Kinerja Tahunan. Pendidikan formal ditempuh melalui tugas belajar dan izin belajar. Kendala dari pendidikan formal karena masih banyak pegawai PKT Kebun Raya-LIPI yang belum mempunyai ijazah SMA, dalam hal ini Subbagian Kepegawaian harus sering memberikan informasi untuk ujian Paket C. Disisi lain, pelatihan ditingkat manajerial, tingkat fungsional dilakukan oleh instansi pelatihan yang sudah terakreditasi oleh LAN. Pelatihan pegawai lainnya terdiri dari pelatihan eksternal maupun internal.

Dibagian akhir Bryson (1999:55) penilaian lingkungan internal dari organisasi bisa dilihat dari kinerja organisasi. Dalam kaitannya dengan kemampuan pegawai, pengembangan yang sudah dilakukan melalui pendidikan dan pelatihan. Pendidikan formal untuk evaluasinya dilakukan oleh lembaga pendidikan masingmasing. Dalam pelatihan eksternal evaluasi dilakukan oleh lembaga penyelenggara diklat masing-masing. 
Pelatihan internal yang direncanakan, diselenggarakan oleh satuan kerja harusnya juga dievaluasi oleh satuan kerja. Namun dalam pelaksanaannya masih banyak pelatihan internal yang belum melaksanakan evaluasi pelatihan secara tertib. Merujuk pada Peraturan Pemerintah tentang Manajemen ASN Pasal 203 (5) menyatakan bahwa untuk menyelenggarakan pengembangan kompetensi PPK wajib melaksanakan evaluasi.Seharusnya dalam akhir pelatihan internal juga dilakukan hal demikian agar dapat mengetahui kebutuhan dari kemampuan dan keterampilan pegawai apakah sudah memenuhi atau belum.

\subsection{Penilaian terhadap Lingkungan Eksternal SDM}

Bryson (1999:55) dalam perencanaan strategis oganisasi publik, langkah ketiga yang dilakukan adalah penilaian terhadap lingkungan eksternal organisasi. Sementara Mathis \& Jackson (2006) tahapan dari perencanaan SDM juga melalui tahapan penilaian lingkungan eksternal akan kebutuhan SDM. Lingkungan diluar organisasi meliputi politik, ekonomi, sosial dan teknologi. Globalisasi yang ditandai dengan adanya keterbukaan informasi dan kompetensi ekonomi antar bangsa menuntut pemerintah untuk lebih giat dalam memperbaiki segala sistem pemerintahnnya. Demi mempercepat terlaksananya reformasi birokrasi, UndangUndang Nomor 5 Tahun 2014 tentang Aparatur Sipil Negara untuk mewujudkan tata kelola aparatur sipil negara sebagai profesi yang memiliki kewajiban mengelola dan mengembangkan dirinya dan mempertanggung jawabkan kinerjanya serta menerapkan prinsip merit dalam pelaksanaan manajemen aparatur sipil Negara.

Untuk mempertegas isi dari Undang-Undang tersebut maka pemerintah mengeluarkan Peraturan Presiden Nomor 11 Tahun 2017 tentang Manajemen Apartur Sipil Negara. Pada Bab V dari PP tersebut disebutkan mengenai pengembangan karier, pengembangan kompetensi, dan sistem informasi manajemen karier. Dalam rangka mencapai karier setiap Aparatur Sipil Negara bertujuan untuk meningkatkan kompetensi dan kinerja ASN. Dalam rangka peningkatan kompetensi yang dimaksud dilakukan dari tiga bidang kompetensi, yakni kompetensi teknis, kompetensi manajerial.

\subsection{Meramalkan Kebutuhan Organisasi}

Perencanaan sumber daya manusia menurut Mathis \& Jackson (2006:53) menyatakan bahwa setelah dilakukan penilaian dari internal maupun eksternal, peramalan dikembangkan untuk mengidentifikasi hubungan antara penawaran dan permintaan SDM dalam organisasi. Dalam hal core capablity pegawai dalam rangka menuju era kompetitif untuk memaksimalkan pegawai menuju competitive zone yang diharapkan PKT
Kebun Raya LIPI telah melakukan pemetaan jabatan khususnya untuk jabatan fungsional. Hasil dari pemetaan jabatan tersebut dapat dilihat pada tabel berikut ini:

Tabel 1 Rekapitulasi Perkiraan Kebutuhan Jabatan Fungsional Peneliti PKT Kebun Raya LIPI

\begin{tabular}{|c|c|c|c|c|c|c|}
\hline \multirow{2}{*}{ No } & \multirow{2}{*}{ Nama Kelti } & \multicolumn{4}{|c|}{ Jenjang } & \multirow{2}{*}{ Kebutuhan } \\
\hline & & Utama & Madya & Muda & Pertama & \\
\hline 1 & Konservasi & 5 & 3 & 6 & 5 & 0 \\
\hline 2 & Domestikasi & 3 & 1 & 10 & 1 & 2 \\
\hline 3 & Reintroduksi & 0 & 2 & 7 & 6 & 3 \\
\hline 4 & $\begin{array}{l}\text { Botani } \\
\text { Ekonomi }\end{array}$ & 1 & 0 & 1 & 4 & 2 \\
\hline
\end{tabular}

Sumber: Pusat Konservasi Tumbuhan Kebun Raya LIPI, 2017

Tabel 2 Rekapitulasi Perkiraan Kebutuhan Jabatan Fungsional Non Peneliti Tingkat Terampil PKT Kebun Raya LIPI

\begin{tabular}{|c|l|c|c|c|c|}
\hline \multirow{2}{*}{ No } & \multirow{2}{*}{ Nama Jabatan } & \multicolumn{4}{|c|}{ Jenjang } \\
\cline { 3 - 6 } & $\begin{array}{c}\text { Pelaksana } \\
\text { Pemula }\end{array}$ & Pelaksana & $\begin{array}{c}\text { Pelaksana } \\
\text { Lanjutan }\end{array}$ & Penyelia \\
\hline 1 & $\begin{array}{l}\text { Analis } \\
\text { Kepegawaian }\end{array}$ & 0 & 1 & 0 & 0 \\
\hline 2 & $\begin{array}{l}\text { Pranata } \\
\text { Humas }\end{array}$ & 0 & 0 & 4 & 2 \\
\hline 3 & Arsiparis & 0 & 1 & 2 & 0 \\
\hline 4 & $\begin{array}{l}\text { Pranata } \\
\text { Komputer }\end{array}$ & 0 & 0 & 1 & 1 \\
\hline 5 & Perencana & 0 & 0 & 0 & 0 \\
\hline 6 & $\begin{array}{l}\text { Pengelola } \\
\text { Pengadaan }\end{array}$ & 0 & 0 & 0 & 0 \\
\hline 7 & $\begin{array}{l}\text { Teknisi } \\
\text { Litkayasa }\end{array}$ & 0 & 0 & 0 & 0 \\
\hline 8 & Pustakawan & 0 & 1 & 0 & 0 \\
\hline
\end{tabular}

Sumber: Pusat Konservasi Tumbuhan Kebun Raya LIPI, 2017

Tabel 3 Rekapitulasi Perkiraan Kebutuhan Jabatan Fungsional Non Peneliti Tingkat Ahli PKT Kebun Raya LIPI

\begin{tabular}{|c|l|c|c|c|c|}
\hline \multirow{2}{*}{ No } & \multicolumn{1}{|c|}{$\begin{array}{c}\text { Nama } \\
\text { Jabatan }\end{array}$} & \multicolumn{5}{|c|}{ Jenjang } \\
\cline { 3 - 6 } 1 & $\begin{array}{l}\text { Analis } \\
\text { Kepegawaian }\end{array}$ & 0 & 0 & 0 & 1 \\
\hline 2 & $\begin{array}{l}\text { Pranata } \\
\text { Humas }\end{array}$ & 0 & 2 & 0 & 0 \\
\hline 3 & Arsiparis & 0 & 0 & 2 & 2 \\
\hline 4 & $\begin{array}{l}\text { Pranata } \\
\text { Komputer }\end{array}$ & 0 & 1 & 1 & 2 \\
\hline 5 & Perencana & 0 & 0 & 0 & 0 \\
\hline 6 & $\begin{array}{l}\text { Pengelola } \\
\text { Pengadaan } \\
\text { Barang/Jasa }\end{array}$ & 0 & 0 & 1 & 1 \\
\hline 7 & $\begin{array}{l}\text { Teknisi } \\
\text { Litkayasa }\end{array}$ & 0 & 0 & 0 & 0 \\
\hline 8 & Pustakawan & 0 & 0 & 1 & 2 \\
\hline
\end{tabular}

Sumber: Pusat Konservasi Tumbuhan Kebun Raya LIPI, 2017

Namun untuk pemenuhan jumlah kebutuhan formasi yang diperlukan satuan kerja harus menunggu peraturan tentang inpassing jabatan fungsional masing-masing. Selain itu kebutuhan PKT Kebun Raya-LIPI, yaitu training need analysis untuk menentukan pelatihan apa yang dibutuhkan oleh setiap pegawai. Dalam training need analysis yang dibuat Tahun 2018 didapatkan sebanyak 17 jenis diklat yang diusulkan dan 
memungkinkan diselenggarakan secara internal. Disisi lain terdapat 27 jenis diklat lain yang tidak memungkinkan untuk dilakukan secara internal. Traning need analysis ini diajukan oleh masing-masing pegawai namun pelatihan yang dibutuhkan bukan merupakan kebutuhan dalam satu tahun melainkan yang dibutuhkan oleh pegawai. Dalam PP tentang Manajemen ASN Pasal 207 (1) disebutkan bahwa penyusunan kebutuhan dan rencana pengembangan kompetensi disusun oleh Pegawai Yang Bersangkutan. Kebutuhan dan rencana pengembangan kompetensi sesuai dengan PP Manajemen ASN tersebut meliputi jenis kompetensi yang perlu dikembangkan; target PNS yang akan dikembangkan kompetensinya; jenis dan jalur pengembangan kompetensi; penyelenggara pengembangan kompetensi; jadwal atau waktu pelaksanaan; kesesuaian pengembangan kompetensi dengan standar kurikulum dari instansi pembina kompetensi; dan anggaran yang dibutuhkan.

\subsection{Merumuskan Strategi Pengembangan SDM}

Terakhir Mathis \& Jackson (2006:53) menyebutkan akhir dari perencanaan SDM adalah merancang strategi SDM serta pelaksanaan program pengembangannya. Dalam hal ini juga disebutkan pada proses perencanaan strategis oleh Bryson (1999:55) bahwa proses perumusan strategi bisa didefinisikan sebagai program pengembangan. Pengembangan kompetensi didasarkan pada sistem merit (UU No 5 Tahun 2014 tentang ASN dan PP Nomor 11 Tahun 2017). Berdasarkan pernyataan tersebut yang diperlukan adalah kompetensi jabatan dan profil pegawai. Kompetensi jabatan sudah diatur dalam aturang masing-masing jabatan fungsional. Profil pegawai di PKT Kebun Raya LIPI sudah direkam pada Sistem Informasi Kepegawaian (SIMPEG) LIPI. Namun menurut wawancara dengan pejabat kepegawaian terkait bahwa informasi profil pegawai terkadang jarang diperbaharui. Hal ini yang menjadikan hambatan proses awal untuk menentukan pengembangan. PP Nomor 11 Tahun 2017 tentang Manajemen ASN pasal 206 (1) menyatakan bahwa:

Untuk menyusun rencana pengembangan kompetensi sebagaimana dimaksud dalam Pasal 205 ayat (1), dilakukan analisis kesenjangan kompetensi dan analisis kesenjangan kinerja.

Analisis kesenjangan kompetensi dapat dilihat dari standar kompetensi masing-masing jabatan dianalisis dengan keadaan profil pegawai sekarang. Selain itu kesenjangan kinerja dapat dinilai dari manajerial melalui penilaian Sasaran Kinerja Pegawai (SKP) dan juga rekam jejak hukuman disiplin. Prinsip sistem merit yang diinginkan pada era kompetitif menuntut adanya keadilan dalam sistem kepegawaian. Analisis jabatan yang telah ada di PKT Kebun Raya-LIPI yag berisi standar kompetensi dapat dijadikan dasar sebagai persyaratan jabatan untuk melakukan pengembangan.

Dalam rangka pengembangan skill dan knowledge yang dibutuhkan pegawai bisa dilakukan dengan dua cara yakni pendidikan dan pelatihan. Grindle (1997:22) menyatakan capacity building dapat dibagi menjadi dimensi pengembangan SDM dengan fokus personil yang profesional dan kemampuan teknis serta tipe kegiatan seperti training, praktek kerja, dan lain-lain. Pendidikan formal ditempuh melalui tugas belajar dan izin belajar pegawai. Kemudian untuk pelatihan dapat berbentuk pelatihan tatap muka di ruangan (pelatihan klasikal) maupun pelatihan non klasikal. Pelatihan tatap muka seperti yang biasa dilakukan bisa dilakukan dalam tahap pelatihan manajerial, fungsional, maupun sosial kultural. Namun ada juga pelatihan yang dapat dilakukan dalam instansi sendiri.

Pengembangan kemampuan pegawai juga dapat dilakukan melalui knowledge management. Karena pada dasarnya pengetahuan pegawai intangible merupakan aset dari suatu organisasi. Sejalan dengan pemikiran Dalkir (2011:5) menyatakan bahwa berkembangnya kemampuan yang saat ini berkembang melalui intangible resources (aset yang tidak berwujud) mengharapkan organisasi harus mengupayakan dan memberdayakan aset tersebut sebagai kemampuan. Knowledge creating activities yang dikemukakan oleh Barton (1995) merupakan aktivitas yang sebenarnya tidak disadari oleh organisasi yang merupakan treatment untuk mendapatkan core capability berupa kemampuan dan pengetahuan pegawai. Core capability dan knowledge creating activities merupakan suatu siklus yang terus berputar dan dapat digunakan terus menerus. Demikian pula untuk PKT Kebun Raya-LIPI yang memiliki SDM kebanyakan rendah dapat mengelola kemampuan mereka agar selalu dapat berkembang.

\section{Kesimpulan}

Pada perencanaan core capability pegawai di PKT Kebun Raya LIPI dapat dilihat melalui tahapan-tahapan, yaitu sebagai berikut:

a) Identifikasi tujuan organisasi: pada tataran implementatif lembaga diwujudkan dalam tujuan strategis satuan kerja yang salah satunya merujuk pada penguatan kompetensi inti di bidang penelitian dan penyiapan bahan-bahan hasil penelitian. Namun tidak menutup kemungkinan kemampuan dari pegawai lain dalam rangka mendukung tujuan strategis tersebut. Sementara itu pada PK (Perjanjian Kinerja) PKT Kebun Raya-LIPI yang merujuk pada Rencana Strategis LIPI, pengembangan SDM menjadi target poin tersendiri untuk dapat dilakukan setiap tahun;

b) Penilaian terhadap lingkungan internal SDM organisasi: penilaian yang dilakukan adalah salah satu dari sumber daya organisasi yakni Sumber Daya 
Manusia (SDM). Strategi (process) yang telah dilaksanakan dalam rangka pengembangan SDM berupa pendidikan dan pelatihan. Kinerja (output) dari strategi yang telah dilaksanakan berupa evaluasi pelatihan internal yang terdokumentasikan pada dokumen ISO 9001:2015 Subbagaian Kepegawaian. Namun dalam pelaksanaannya evaluasi pelatihan internal belum dijalankan dengan maksimal. Selain itu dalam hal penganggaran untuk pengembangan SDM belum memiliki porsi tersendiri dari anggaran satuan kerja. Di PKT Kebun Raya-LIPI hanya ada anggaran khusus bagi Diklat Teknis dan Manajemen Perkebunrayaan;

c) Penilaian terhadap lingkungan eksternal SDM organisasi: pada Bab V dari PP Nomor 11 Tahun 2017 tentang Manajemen ASN disebutkan mengenai pengembangan karier, pengembangan kompetensi, dan sistem informasi manajemen karier. Dalam rangka mencapai karier setiap Aparatur Sipil Negara bertujuan untuk meningkatkan kompetensi dan kinerja ASN. Dalam rangka peningkatan kompetensi yang dimaksud dilakukan dari tiga bidang kompetensi, yakni kompetensi teknis, kompetensi manajerial;

d) Meramalkan kebutuhan SDM: pada Tahun 2017 PKT Kebun Raya LIPI telah melakukan pemetaan kebutuhan pegawai khususnya untuk jabatan fungsional. Training need analysis juga disusun untuk menentukan kebutuhan pelatihan pegawai namun penyusunan kebutuhan dan rencana pengembangan kompetensi belum sesuai dengan PP tentang Manajemen ASN Pasal 207 (1); dan

e) Merumuskan strategi pengembangan SDM: profil pegawai yang ada pada Sistem Informasi Kepegawaian LIPI harus selalu diperbaharui. Hal tersebut untuk menentukan kesenjangan kompetensi (competency gap) yang disesuaikan dengan syarat kompetensi pada masing-masing jabatan fungsional. Dengan memperhatikan analisis jabatan fungsional yang sudah ada, dapat dijadikan pedoman untuk melakukan pengembangan. Selain itu, analisis kesenjangan kinerja juga diperlukan melalui penilaian Sasaran Kinerja Pegawai (SKP) dan penilaian hukuman disiplin pegawai. Pengembangan SDM sendiri dapat melalui pendidikan dan pelatihan baik dalam tataran manajerial, fungsional, maupun sosial kultural. Barton (1995) menyatakan adanya aktivitas untuk membentuk dan memlihara kemampuan inti yakni yang disebut knowledge creating activities. Aktivitas manajemen kreasi pengetahuan ada empat, yaitu: pemecahan masalah bersama, integrasi alat dan metodologi baru, eksperimen, dan penyusunan prototipe, dan penyerapan pengetahuan dari luar. Proses pemecahan masalah bersama dapat dilakukan melalui diskusi maupun pertemuan antar pegawai.
Integrasi alat dan metodologi baru dapat dilakukan melalui penggunaan alat untuk menunjang terbentuknya pengetahuan. Dalam eksperimen dan penyusunan protipe diimplementasikan melalui adanya proses yang dilakukan melalui kemampuan antar pegawai untuk membentuk produk unggul organisasi. Terakhir agar pengetahuan yang ada tetap sustain dan berkembang adanya penyerapan pengetahuan baik dari luar maupun dalam organisasi. Dalam hal ini melakukan knowledge creating activities harus mendapatkan dukungan dari peran manajerial dan juga melibatkan semua lini pegawai. Agar knowledge yang bersifat tangible maupun intangible dapat terbentuk menjadi kemampuan inti organisasi.

\section{Daftar Pustaka}

Barton, Leonard D. (1995). Wellspring Knowledge, Building and Sustaining The Source of Innovation. London: Harvard Business School.

Bryson, John M. (1999). Perencanaan Strategi Organisasi Sosial (Penerjemah M. Miftahudin). Pustaka Pelajar, Yogyakarta.

Bryson, John M. (2004). Third Edition Strategic Planning for Public and Non Profit Organizations. USA : Jossey Bass.

Dalkir, K. (2005). Knowledge Management in Theory and Practice. Oxford (GB): Elsevier ButterworthHeinemann.

Faludi, Andreas. (1973). Planning Theory, Reprinted 1976. Oxford: Pergamon Press.

Grindle, M.S. (1997). Getting Good Government: Capacity Building in the Public Sector of Developing Countries. MA Boston: Harvard Institute for International Development.

Mathis, R.L., \& J.H. Jackson. (2006). Human Resource Management: Manajemen Sumber Daya Manusia - Terjemahan Dian Angelia. Jakarta: Salemba Empat.

Miles, Matthew B., A. Michael Huberman., \& Johnny Saldana. (2014). Qualitative Data Analysis: A Methods Sourcebook. Thousand Oaks, CA: Sage.

Muluk, Khairul. (2008). Knowledge Management: Kunci Sukses Inovasi Pemerintahan Daerah. Malang: Bayumedia Publishing.

Pusat Konservasi Tumbuhan Kebun Raya LIPI. (2017). Laporan Bulanan Subbagian Kepegawaian Tahun 2017. Bogor: LIPI.

Prahalad, C. K., \& Hamel, Gary. (1990). The Core Competence of the Corporation. Harvard Business Review, Vol. 68, Issue 3, pp. 79-91.

Peraturan Pemerintah Nomor 11 Tahun 2017 tentang Manajemen Aparatur Sipil Negara. 
Thoha, Miftah. (2008). Reformasi Pemerintah Indonesia di Era Reformasi. Jakarta: Prenada Media Group.

Undang-Undang Nomor 17 Tahun 2007 tentang RPJPN 2005-2025. 